\title{
Efeito de Exsudatos Radiculares em Endósporos de Pasteuria penetrans e em Juvenis do Segundo Estádio de Meloidogyne incognita*
}

\author{
Fernando da Silva Rocha**, Vicente P. Campos \& Ricardo Magela de Souza \\ Universidade Federal de Lavras, Departamento de Fitopatologia, CEP 37200-000, Cx. Postal 37, Lavras, MG, \\ fax (035) 3829-1283, e-mail: rocha.fs@bol.com.br
}

(Aceito para publicação em 22/09/2004)

Autor para correspondência: Fernando S. Rocha

ROCHA, F.S., CAMPOS, V.P. \& SOUZA, R.M. Efeito de exsudatos radiculares em endósporos de Pasteuria penetrans e em juvenis do segundo estádio de Meloidogyne incognita. Fitopatologia Brasileira 29:644-650. 2004.

\section{RESUMO}

Juvenis do segundo estádio (J2) de Meloidogyne incognita foram incubados nos exsudatos radiculares de soja (Glycine max), tomateiro (Lycopersicon esculentum), cafeeiro (Coffea arabica), feijoeiro (Phaseolus vulgaris), mostarda (Brassica rapa), Crotalaria juncea e C. spectabilis e em água por $12 \mathrm{~h}$. Em seguida, realizouse o teste de adesão por centrifugação ou por borbulhamento. Em outro ensaio, endósporos de Pasteuria penetrans foram incubados por quatro dias a $26{ }^{\circ} \mathrm{C}$ nos exsudatos e submetidos à adesão em J2 de M. incognita, sob borbulhamento constante por $24 \mathrm{~h} \mathrm{em}$ tubos contendo água. Os $\mathrm{J} 2$ com endósporos aderidos pelo teste de borbulhamento foram inoculados em mudas de tomateiro. Verificou-se que a incubação dos $\mathrm{J} 2$ por $12 \mathrm{~h}$ nos exsudatos radiculares testados reduziu o número de endósporos de $P$. penetrans por $\mathrm{J} 2$ independentemente do método de adesão empregado. Os $\mathrm{J} 2$ incubados nos exsudatos radiculares testados proporcionaram menor número de fêmeas parasitadas em tomateiro em relação à testemunha (água), bem como menor número de galhas com exceção dos J2 incubados em exsudato do próprio tomateiro. A reprodução dos J2 incubados nos exsudatos radiculares não foi afetada quando comparada à testemunha. A incubação dos endósporos nos exsudatos das plantas testadas reduziu a adesão e a infetividade em $\mathrm{J} 2$, em relação à testemunha. Após 28 dias da inoculação, observou-se redução no número de fêmeas parasitadas resultantes da infecção desses $\mathrm{J} 2$ com endósporos incubados em exsudatos radiculares comparada com aqueles incubados em água. O parasitismo do J2 com endósporos tratados com exsudatos radiculares e a reprodutividade de fêmeas oriundas da infetividade desses J2 foram semelhantes aos incubados em água.

Palavras-chave adicionais: parasitismo, infetividade, controle biológico, nematóide de galhas, bactéria.

\section{ABSTRACT}

Effect of root exudates on endospores of Pasteuria penetrans and on second-stage juvenile of Meloidogyne incognita

In one assay, second stage juveniles (J2) of Meloidogyne incognita were incubated in root exudates of soybean (Glycine max), tomato (Lycopersicon esculentum), coffee (Coffea arabica), bean (Phaseolus vulgaris), mustard (Brassica rapa), Crotalaria juncea and $C$. spectabilis and in water for $12 \mathrm{~h}$, followed by endospores adhesion by centrifugation or by air bubbling. In another assay, endospores of Pasterius penetrans were incubated for four days at 26 ${ }^{\circ} \mathrm{C}$ in the exudates and submitted to adhesion on $\mathrm{J} 2$ of $M$. incognita by constant air bubbling for $24 \mathrm{~h}$ in tubes containing water. The $\mathrm{J} 2$ with endospore adhesion by air bubbling were inoculated in tomato seedlings. The incubation of $\mathrm{J} 2$ for $12 \mathrm{~h}$ in the root exudates reduced the number of $P$. penetrans endospore per $\mathrm{J} 2$, regardless of the adhesion test used, and resulted in fewer parasitized females when compared with the control, as well as a lower number of galls, except in the $\mathrm{J} 2$ incubated in exudate of tomato. The reproduction of incubated $\mathrm{J} 2$ in the root exudates was not affected when compared to the control. The endospore incubation in the exudates of the tested plants reduced the adhesion and the infectivity of these endospores to $\mathrm{J} 2$ in relation to the control. After 28 days from inoculation, reduction was observed in the number of parasitized females resulting from infection of those $\mathrm{J} 2$ with endospore incubated in exudates when compared with those incubated in water. The parasitism of $\mathrm{J} 2$ with endospore treated with exudates and the reproduction of infected $\mathrm{J} 2$ females were similar to those incubated in water.

\section{INTRODUÇÃO}

Os nematóides do gênero Meloidogyne possuem uma relação parasitária com as raízes de diversas plantas, além de patogênica para muitas culturas, causando enormes prejuízos à agricultura brasileira e mundial (Lordello, 1984; Luc et $a l .$, 1990). Esse parasitismo não ocorre, contudo, em algumas

\footnotetext{
* Parte da Dissertação de Mestrado do primeiro autor. Universidade Federal de Lavras (2003).

** Bolsista da CAPES
}

plantas, sendo estas então empregadas como medidas de controle ( Ferraz \& Valle, 1997; Costa et al., 2000; Santiago et al., 2001). Em algumas delas ocorrem em seus exsudatos substâncias nematicidas e nematostáticas a juvenis do segundo estádio (J2), levando-os à morte ou reduzindo sua mobilidade (Gommers, 1981; Campos et al., 2002). Em outras plantas, entretanto, essas substâncias encontram-se pré-formadas em seus tecidos ( Badra et al., 1979; Nogueira et al., 1994) sendo liberadas quando a planta é incorporada ao solo. O exsudato e os tecidos das plantas em decomposição servem também 
Efeito de exsudatos radiculares em endósporos de Pasteuria penetrans...

como fonte de alimento para muitos organismos do solo, além de afetar fases do ciclo das relações entre eles (Guckert, 1992; Siqueira, 1997). Um desses organismos é a bactéria Pasteuria penetrans (Thorne, 1940) Sayre \& Starr, 1995, cuja adesão do endósporo em $\mathrm{J} 2$ de Meloidogyne spp. é inibida por metabólicos secundários de fungos e bactérias (Rocha \& Campos, 2000; Maximiniano et al., 2001d). A aderência desse endósporo ao $\mathrm{J} 2$ de Meloidogyne spp. constitui o inicio do ciclo de vida da bactéria além de propiciar a continuação desse ciclo através de gerações do nematóide. Por isso, a natureza desse processo de adesão tem sido investigada por muitos pesquisadores (Stirling et al., 1986; Ratnasoma et al., 1991; Davies \& Danks, 1993; Spiegel et al., 1996). Maximiniano et al. (2001b) verificaram que solo argiloso e substrato de folhas moídas de Crotalaria juncea L. reduziram a adesão de endósporos de $P$. penetrans a J2 de $M$. javanica (Treub) Chitwood. Rocha \& Campos (2000) e Maximiniano et al. (2001d) verificaram que filtrados fúngicos de Arthrobotrys conoides Drechsler e Paecilomyces lilacinus (Thom) Samson e de rizobactérias antagônicas a Meloidogyne spp. reduziram a adesão do endósporo de $P$. penetrans em $M$. incognita (Kofoid $\&$ White) Chitwood e $M$. javanica, respectivamente. Freitas et al. (2000) observaram que a incorporação de folhas de repolho ao solo, seguido de incubação a $50{ }^{\circ} \mathrm{C}$ por dez dias afetaram a formação de endósporos no interior da fềmea de $M$. arenaria (Neal) Chitwood.

Para encontrar o endósporo de $P$. penetrans no solo o $\mathrm{J} 2$ de Meloidogyne spp. precisa movimentar-se em sua direção, o que pode ser influenciado, entre outros, por produtos da degradação de tecidos de plantas e pelos exsudatos radiculares afetando talvez a interação $P$. penetransMeloidogyne spp., porém, esse efeito ainda não foi estudado. Desta forma, objetivou-se, neste trabalho, avaliar o efeito de exsudatos radiculares de diversas plantas em juvenis do segundo estádio (J2) de $M$. incognita e nos endósporos de $P$. penetrans e na adesão e infetividade desse nematóide.

\section{MATERIAL E MÉTODOS}

\section{Desinfestação das sementes}

Sementes de mostarda (Brassica rapa L.), café (Coffea arabica L.) cv. Rubi, feijão (Phaseolus vulgares L.) cv. Carioca, C. juncea e C. spectabilis L. foram colocadas em copos de $250 \mathrm{ml}$ contendo solução de sulfato de estreptomicina $1 \%$ e uma gota de Tween $80 \%$. No caso das sementes de café, o pergaminho foi retirado antes do tratamento acima descrito. Sementes de tomate (Lycopersicon esculentum Mill.) cv. Kada e de soja (Glycine max L.) cv. Doko-RC foram tratadas por 5 min e as demais por $30 \mathrm{~min}$, como descrito acima. A seguir, a solução de sulfato de estreptomicina foi descartada e adicionada solução de hipoclorito de sódio $1 \%$ sobre as sementes, de modo a ficarem imersas. Sementes de café, feijão, tomate e soja ficaram imersas por $1 \mathrm{~min}$ e as demais por $30 \mathrm{~min}$. A seguir, procedeu-se à lavagem por quatro vezes consecutivas com água destilada e esterilizada para retirar o excesso do hipoclorito de sódio.

\section{Obtenção das plântulas}

Após a desinfestação superficial, em câmara de fluxo laminar, as sementes foram distribuídas em bandejas plásticas, previamente desinfestadas com álcool $95 \%$, as quais continham areia passada em peneira de aberturas de malhas $0,850 \mathrm{~mm}$ e esterilizada através da tríplice autoclavagem à $120{ }^{\circ} \mathrm{C}$ por $30 \mathrm{~min}$. A seguir, as bandejas foram vedadas com filme plástico (rolopack $\AA$ ) e transferidas para câmara climatizada com $14 \mathrm{~h}$ de luz e $10 \mathrm{~h}$ de escuro à temperatura de $28 \pm 2{ }^{\circ} \mathrm{C}$, para permitir a germinação. As plantas foram utilizadas para obtenção do exsudato radicular em diferentes idades de acordo com a abundância de raízes observada visualmente (Tabela 1).

\section{Extração dos exsudatos radiculares das plântulas}

As plântulas foram retiradas cuidadosamente das bandejas, em câmara de fluxo laminar, e as raízes foram separadas da parte aérea com bisturi e transferidas para placa de Petri contendo papel de filtro estéril e umedecido com água destilada e esterilizada. As plântulas de café utilizadas para extração do exsudato radicular encontravam-se no estágio de palito de fósforo. Para obtenção dos exsudatos radiculares das plantas testadas (Tabela 1), utilizou-se a técnica adaptada de Campos et al. (2002). Para isso, as raízes foram colocadas em tubo plástico cônico de $45 \mathrm{~mm}$ de altura por $10 \mathrm{~mm}$ de diâmetro superior e $4 \mathrm{~mm}$ de diâmetro inferior, o qual foi seccionado na parte inferior e recoberto com membrana Millipore de 10,0 $\mu \mathrm{m}$ de diâmetro de poro. Todo o conjunto foi encaixado pela parte do menor diâmetro noutro tubo de $10 \mathrm{~mm}$ de diâmetro. Em seguida, o tubo superior contendo as raízes foi vedado em sua extremidade e todo o conjunto formado pelos dois tubos acoplados foi centrifugado a $1.890 \mathrm{~g}$ por $10 \mathrm{~min}$. Na centrifugação, o exsudato radicular passou pela membrana Millipore sendo coletado no tubo inferior e daí retirado com pipeta automática de 1,0 $\mathrm{ml} \mathrm{e}$ diluído para a concentração de 1:10. Esse exsudato radicular diluído foi passado em membrana Millipore de 0,22 $\mu \mathrm{m}$ de diâmetro de poro, obtendo-se assim solução estéril, sendo então armazenado no escuro a $-4^{\circ} \mathrm{C}$, em refrigerador, até sua utilização.

TABELA 1 -Idade das plântulas das diversas espécies vegetais usadas na obtenção do exsudato radicular, $\mathrm{pH}$ dos exsudatos e número de plântulas necessárias para obtenção de $1 \mathrm{ml}$ de exsudato

\begin{tabular}{lccc}
\hline \hline Espécies vegetais & $\begin{array}{c}\text { Idade das } \\
\text { plântulas } \\
\text { (dias) }\end{array}$ & $\begin{array}{c}\text { No de plântulas / } \\
\mathbf{1} \text { ml de exsudato }\end{array}$ & pH \\
\hline Soja & 7 & 56 & 7,50 \\
Tomate & 13 & 132 & 7,38 \\
Café & 28 & 30 & 6,20 \\
Feijão & 8 & 25 & 6,49 \\
Mostarda & 8 & 140 & 5,78 \\
C. juncea & 6 & 57 & 6,65 \\
C. spectabilis & 8 & 55 & 7,62 \\
\hline
\end{tabular}




\section{Obtenção de mudas de tomateiro}

Sementes de tomateiro, cv. Kada, do grupo Santa Cruz, foram semeadas em bandejas contendo substrato Plantmax e mantidas em casa de vegetação. Mudas saudáveis e de tamanho ideal para o transplantio e montagem dos ensaios foram obtidas 35 dias após a semeadura.

\section{Obtenção dos endósporos de Pasteuria penetrans}

Os endósporos de $P$. penetrans, isolado $\mathrm{PP}_{12}$ originário do município de Ijaci, $\mathrm{MG}$, foram multiplicados em raízes de tomateiros cultivados em vasos ou bandejas mantidos em casa de vegetação. As raízes de tomateiro foram separadas do substrato, lavadas em água, cortadas em pedaços de $2 \mathrm{~cm}$ e embebidas por $24 \mathrm{~h}$ em solução enzimática composta de 4,0 $\mathrm{ml}$ de pectinase-SIGMA P-9179 e 4,0 g de cellulase-SIGMA $\mathrm{C}-1184$. A seguir, as raízes foram trituradas em liquidificador por $40 \mathrm{~s}$ e vertidas em peneira de $0,84 \mathrm{~mm}$ sobre peneira de $0,025 \mathrm{~mm}$, coletando-se o material retido nessa última peneira em Erlenmeyer de 21 . As fêmeas de $M$. incognita contidas nesse material foram retiradas com o auxílio de um estilete de ponta recurvada e colocadas em tubo de ensaio contendo solução tampão de fosfato de sódio $0,05 \mathrm{M}$ e pH 7,0. Essas fêmeas parasitadas por $P$. penetrans foram esmagadas em 2 $\mathrm{ml}$ de água destilada, em triturador de tecidos (Pyrex 772715) previamente lavado com leite desnatado e enxaguado com água destilada. Esse procedimento foi realizado para todos os recipientes em contato com os endósporos. Essa suspensão de $P$. penetrans foi passada por peneira de $0,028 \mathrm{~mm}$ para retirada de restos de fêmeas e/ou ovos, obtendo-se uma suspensão límpida de endósporos quantificada através de câmara de Newbauer e armazenada a $8{ }^{\circ} \mathrm{C}$ em câmara fria. Essa suspensão foi pré-tratada em sonificador durante $20 \mathrm{~min}$, antes do teste de adesão.

\section{Obtenção de juvenis do segundo estádio (J2) de Meloidogyne incognita}

Raízes de tomateiros cv. Kada cultivadas em casa de vegetação e infestadas com $M$. incognita, foram lavadas cuidadosamente e cortadas em pedaços de aproximadamente um centímetro. Os ovos foram obtidos conforme técnica de Hussey \& Barker (1973). Ao final, o material retido na peneira de $0,025 \mathrm{~mm}$ foi recolhido com o auxílio de jatos de sacarose $(0,5 \mathrm{~g} / \mathrm{ml})$, em tubos de plástico de $50 \mathrm{ml}$. Em seguida, colocaram-se aproximadamente $3 \mathrm{~g}$ de caulim nesses tubos, que foram agitados para colocar em suspensão todo o precipitado e, a seguir, centrifugados por $60 \mathrm{~s}$ a $680 \mathrm{~g}$. Transcorrido esse tempo, derramou-se o sobrenadante numa peneira de $0,025 \mathrm{~mm}$, sem agitar o precipitado. Recolheram-se os ovos retidos na peneira em béquer de $200 \mathrm{ml}$, utilizando-se pisseta contendo água destilada. Em câmara de fluxo laminar, toda a suspensão foi lavada por quatro vezes em água destilada e esterilizada, utilizando-se peneira desinfestada de $0,025 \mathrm{~mm}$ e, então, colocada em béquer de vidro esterilizado. Para a obtenção dos J2, utilizou-se câmara de eclosão formada com tela e papel celulose de lenços duplos de 14,8 × $21,5 \mathrm{~cm}$ (Klin $\left.{ }^{\circledR}\right)$ montada em funil de vidro esterilizado.

\section{Montagem e avaliação dos ensaios}

No primeiro ensaio, os $\mathrm{J} 2$ de $M$. incognita, obtidos conforme descrito anteriormente, foram recolhidos no terceiro dia, quantificados em microscópio de objetiva invertida e separados em oito porções para a montagem do ensaio empregando-se exsudatos radiculares de sete plantas (Tabela 1) e água como testemunha. $\mathrm{O}$ delineamento experimental foi inteiramente casualizado, com cinco repetições. Cada porção de J2 foi vertida sobre peneira formada de tela Millipore de $11 \mu \mathrm{m}$ de diâmetro de poro e recolhida em 500 $\mu 1$ de solução de exsudato radicular diluído 1:10 (exsudato: água) de cada planta (Tabela 1) ou água (testemunha), para tubos de eppendorf com capacidade para 1,5 ml, e em seguida incubada por $12 \mathrm{~h}$ a $26^{\circ} \mathrm{C}$ no escuro. Após a incubação, os J2 foram vertidos sobre peneira formada de tela Millipore de 11 $\mu \mathrm{m}$ para retirar-se o exsudato e recolhidos com água destilada para outro tubo de eppendorf. Para o teste de adesão dos endósporos, utilizou-se o método de centrifugação (Hewlett \& Dickson, 1993) com modificações. Para isto, $500 \mu l$ de água destilada contendo $100 \mathrm{~J} 2$ foram adicionados em tubos de eppendorf, juntamente com $150 \mu \mathrm{l}$ da suspensão de endósporo de $P$. penetrans na concentração de $1,2 \times 10^{6}$ endósporos $/ \mathrm{ml}$. Após a centrifugação dos tubos a $800 \mathrm{~g}$ por 3 min a $30^{\circ} \mathrm{C}$, transferiu-se o conteúdo dos tubos para caixa de contagem. Em microscópio de objetiva invertida com aumento de 250x, quantificou-se o número de $\mathrm{J} 2$ com endósporos aderidos, para o cálculo de percentagem de adesão, e o número de endósporo/J2.

Os dados obtidos foram submetidos ao teste de Hartley (Banzatto \& Kronka, 1995), no qual se verificou a homocedasticidade. Em seguida, foram submetidos à analise de variância e teste de Tukey, a 5\% de probabilidade, para a comparação das médias.

No segundo ensaio, os J2 de $M$. incognita foram incubados nos exsudatos radiculares das sete plantas testadas (Tabela 1) e na água como testemunha por $12 \mathrm{~h}$, à semelhança do ensaio anterior. A seguir foram recolhidos em solução tampão de fosfato de sódio $0,05 \mathrm{M}$ e pH 7,0 e colocados em tubo de vidro de $145 \mathrm{~mm}$ de altura por $14 \mathrm{~mm}$ de diâmetro. $\mathrm{O}$ ensaio foi montado em delineamento inteiramente casualizado, com oito tratamentos e cinco repetições. Adicionaramse $2 \mathrm{ml}$ de uma suspensão de endósporos de $P$. penetrans com $1,2 \times 10^{6}$ endósporos $/ \mathrm{ml}$, em cada tubo contendo $1.000 \mathrm{~J} 2 \mathrm{de}$ $M$. incognita pré-tratados com exsudato radicular como descrito anteriormente, completando-se o volume final dos tubos para $12 \mathrm{ml}$ com solução tampão. Em seguida, mangueira plástica ligada à bomba de aquário foi inserida no tubo com sua extremidade imersa na suspensão de juvenis e endósporos para borbulhamento constante por $24 \mathrm{~h}$. Ao final desse tempo, o conteúdo de cada tubo foi passado em peneira de $0,037 \mathrm{~mm}$ e lavado em água corrente para a retirada dos endósporos não aderidos ao J2. Para quantificação dos endósporos aderidos, os $\mathrm{J} 2$, em número de 20 , escolhidos ao acaso, por tubo, foram observados em microscópio de objetiva invertida no aumento de $250 \mathrm{x}$, contando-se o número de endósporos aderidos por $\mathrm{J} 2$ e o número de $\mathrm{J} 2$ com endósporos aderidos 
para o cálculo de percentagem de adesão. A análise de variância e o teste de médias foram semelhantes ao ensaio anterior.

No terceiro ensaio, $5 \mathrm{ml}$ de uma suspensão de endósporo de $P$. penetrans na concentração de $2,8 \times 10^{7}$ endósporos/ $\mathrm{ml}$ foram centrifugados a $800 \mathrm{~g}$ por $10 \mathrm{~min}$, em tubos de 20 $\mathrm{ml}$, com os endósporos formando o precipitado. O sobrenadante foi removido com pipeta automática. Utilizaram-se exsudatos radiculares de diversas plantas (Tabela 1). Cinco mililitros desses exsudatos foram diluídos 1:10 (exsudato: água) e neles foram ressuspensos os endósporos e incubados por quatro dias à temperatura de $26{ }^{\circ} \mathrm{C}$. Na testemunha os endósporos foram incubados em água. $\mathrm{O}$ delineamento experimental foi inteiramente casualizado, com oito repetições. Ao final desse tempo, foram feitas duas novas centrifugações: a primeira para retirar o exsudato radicular e a outra para promover a lavagem dos endósporos com água destilada, na mesma velocidade anteriormente citada. Os endósporos ainda dentro dos tubos foram ressuspensos em aproximadamente 1 $\mathrm{ml}$ de água destilada, sendo adicionados em cada tubo 1.000 $\mathrm{J} 2$ de $M$. incognita, inserindo-se uma mangueira plástica ligada à bomba de aquário para borbulhamento constante da suspensão por $24 \mathrm{~h}$. A seguir, o conteúdo de cada tubo foi passado em peneira de $0,037 \mathrm{~mm}$ e lavado em água corrente para a retirada dos endósporos não aderidos aos $\mathrm{J} 2$. Em vinte $\mathrm{J} 2$ escolhidos ao acaso, por tubo, foi contado em microscópio de objetiva invertida, aumento de $250 x$, o número de endósporos $/ \mathrm{J} 2$ e o número de $\mathrm{J} 2$ com endósporos. A análise de variância e o teste de médias foram semelhantes ao ensaio anterior.

No quarto ensaio, $1.000 \mathrm{~J} 2$ de $M$. incognita após incubação por $12 \mathrm{~h}$ em exsudato radicular de cada uma das sete plantas estudadas (Tabela 1) e em água (testemunha), seguida da adesão com endósporos de $P$. penetrans, ou com $1.000 \mathrm{~J} 2$ de $M$. incognita com endósporos aderidos e tratados com os mesmos exsudatos radiculares foram inoculados em mudas de tomateiro colocadas em copos plásticos de $300 \mathrm{ml} \mathrm{de}$ volume contendo substrato na proporção 1:1 (solo: areia). $\mathrm{O}$ delineamento experimental foi inteiramente casualizado, com oito tratamentos e oito repetições. Para inoculação, esses J2 foram dispersos em $4 \mathrm{ml}$ de água e colocados em 4 furos de \pm $3 \mathrm{~cm}$ de profundidade ao redor das mudas. A seguir, os copos foram colocados em sala climatizada com temperatura de 28 $\pm 2{ }^{\circ} \mathrm{C}$, fotoperíodo de $14 \mathrm{~h}$ de luz e mantidos nessas condições durante 28 dias. Ao final desse tempo, cortou-se a parte aérea e retirou-se, cuidadosamente, o sistema radicular do solo em água parada num balde de $15 \mathrm{l}$. Em seguida, foram extraídas quarenta fêmeas por tratamento e esmagadas em lâminas. Em microscópio de objetiva invertida, aumento de 500x, contou-se o número de fêmeas parasitadas. Consideraram-se parasitadas todas aquelas com endósporos encontrados no seu interior. A seguir, todo o sistema radicular foi colocado em solução de Floxina B $0,0015 \%$ por 15 min, colorindo-se de vermelho as massas de ovos dos nematóides. Após a coloração, as raízes foram deixadas sobre papel toalha por $10 \mathrm{~min}$, possibilitando assim a avaliação do peso da matéria fresca das raízes, seguida da contagem do número de massas de ovos e de galhas por sistema radicular. Para quantificação do número de ovos por sistema radicular, as raízes foram cortadas em pedaços de aproximadamente $2 \mathrm{~cm}$ de comprimento e os ovos obtidos pela técnica de Hussey \& Barker (1973). Em microscópio de objetiva invertida estimou-se o número de ovos de $M$. incognita por sistema radicular. Os dados obtidos foram transformados em $\sqrt{x+0.5}$ para análise de variância e as médias comparadas pelo teste de Tukey a 5\% de probabilidade.

\section{RESULTADOS E DISCUSSÃO}

\section{Efeito na adesão e na infetividade de endósporos de $\boldsymbol{P}$. penetrans sobre $\mathrm{J} 2$ de $M$. incognita incubados nos exsudatos radiculares}

Todos os exsudatos radiculares testados em que se incubaram os juvenis do segundo estádio (J2) de $M$. incognita por $12 \mathrm{~h}$ reduziram $(\mathrm{P} \leq 0,05)$ o número de endósporos de $P$. penetrans $/ \mathrm{J} 2$, percentagem de adesão e de fêmeas infetadas em comparação à testemunha água (Figuras 1, 2 e 3). Os exsudatos das plantas testadas (Tabela 1$)$ reduziram $(\mathrm{P} \leq 0,05)$ a adesão dos endósporos em $\mathrm{J} 2$ independentemente da técnica usada para promover essa adesão, qual seja centrifugação ou borbulhamento (Figuras 1 e 2). Os J2 incubados nos exsudatos das plantas testadas causaram menor número de galhas em tomateiros comparados à testemunha (água), com exceção dos J2 incubados em exsudatos de tomateiro (Figura 4). A reprodutividade em tomateiro (número de ovos/ massa de ovos por grama de raiz) dos $\mathrm{J} 2$ incubados nos exsudatos das plantas de café (652/6), mostarda (595/8) e C. juncea (769/9), não diferiram da testemunha $(816 / 10)$.

A incubação de $\mathrm{J} 2$ nos exsudatos deve ter causado alterações na cutícula desse nematóide afetando algum promotor da adesão dos endósporos, ainda desconhecido. Spiegel et al. (1996) verificaram que o pré-tratamento dos J2 de $M$. javanica com o detergente dodecil sulfato de sódio, lectinas concavalina A e aglutamina do germe do trigo reduziram a adesão dos endósporos à cutícula dos J2. Outras substâncias como enzimas (quitinase, muramidase, proteinase $\mathrm{K}$, pepsina A, lípase, hialuronidase, $\alpha$-glucosidase, celulase), ácido siálico e açúcares (fucose ou $\alpha$-metil manosideo, $\mathrm{N}$ acetil-D-glucosamine, D-xilose), quando empregadas na incubação do J2 de Meloidogyne sp., diminuíram a adesão dos endósporos de P. penetrans ( Stirling et al., 1986; Davies \& Danks, 1993; Spiegel et al., 1996; Maximiniano et al., 2001a). Substâncias semelhantes podem estar presentes nos exsudatos das plantas. De fato, Rovira (1969) constatou a presença de açúcares (glucose, xilose, ribose, frutose, arabinose, oligosacarídeos, etc), enzimas (protease, amilase, etc), ácidos orgânicos (acético, málico, cítrico, butírico, etc), aminoácidos (leucina, glicina, alanina, ácido glutâmico, ácido aspartico, asparagina, etc) no exsudato de trigo. Essas substâncias também têm sido encontradas em exsudatos de ervilha, aveia, feijão e tomate (Rovira, 1959; Rovira, 1969; Hale et al., 1971; Tanda et al., 1989). A composição diversificada e a quantidade desses exsudatos no solo criam condições 
A

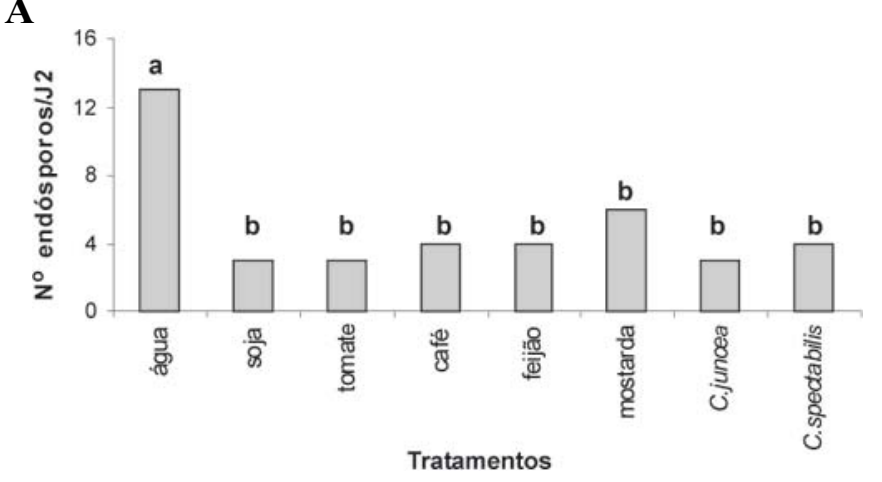

B

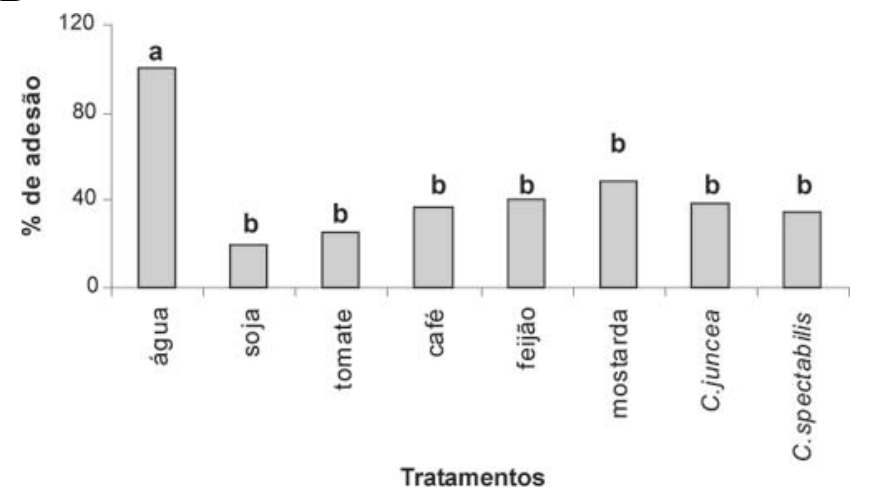

FIG. 1 - Efeito do exsudato radicular de soja (Glycine max), tomateiro (Lycopersicon esculentum), cafeeiro (Coffea arabica), feijoeiro (Phaseolus vulgaris), mostarda (Brassica rapa), Crotalaria juncea e C. spectabilis sobre juvenil do segundo estádio (J2) de Meloidogyne incognita em incubação por $12 \mathrm{~h}$ (ensaio 1), seguido da adesão por centrifugação do endósporo de Pasteuria penetrans. A) número de endósporos/J2; B) percentagem de adesão. Barras seguidas pela mesma letra não diferem significativamente entre si pelo teste de Tukey a $5 \%$ de probabilidade.

adversas à adesão de endósporos de $P$. penetrans em $\mathrm{J} 2$ de Meloidogyne sp., diminuindo a eficácia do parasitismo e propiciando que parte da população do nematóide sempre se mantenha livre dessa infecção, além de trazer equilíbrio populacional durante o crescimento da cultura.

A redução na percentagem de adesão dos endósporos no J2 pelo efeito dos exsudatos (Figura 1B), demonstra que a maioria dos indivíduos foi afetada, o que poderia, no campo, diminuir a infetividade de P. penetrans em M. incognita. De fato, a infetividade dos endósporos foi reduzida quando avaliada pelo número de fêmeas de $M$. incognita infetadas (Figura 3). Tariq et al. (2000) trabalhando com extrato foliar de Datura stramonium L. encontraram redução na adesão dos endósporos de P. penetrans em $\mathrm{J} 2$ de $M$. javanica após aplicação desse extrato em solo infestado pela bactéria. O pré-tratamento de ambos, J2 de $M$. javanica e dos endósporos, com ácido siálico e pectinase, diminuiu a adesão de endósporos de $P$. penetrans em $\mathrm{J} 2$ de $M$. javanica (Stirling et al., 1986; Maximiniano et al., 2001a), ratificando a idéia de que na rizosfera o exsudato radicular pode realmente concorrer para diminuir a infetividade de $P$. penetrans em fitonematóides

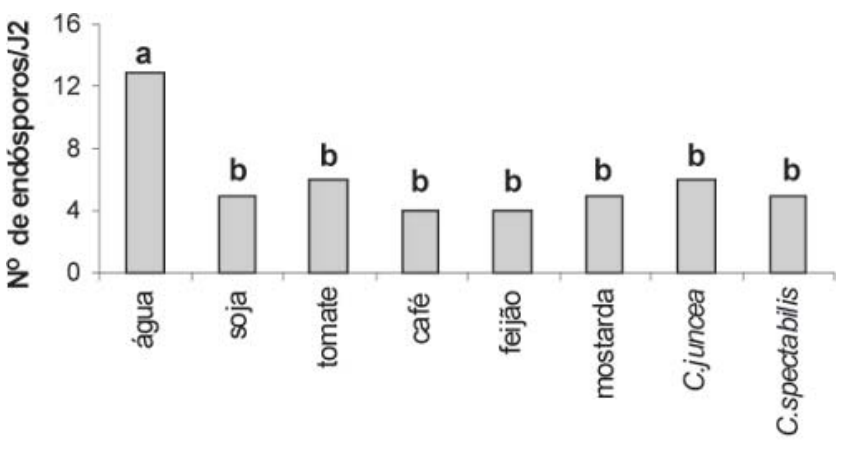

Tratamentos

FIG. 2 - Efeito do exsudato radicular de soja (Glycine max), tomateiro (Lycopersicon esculentum), cafeeiro (Coffea arabica), feijoeiro (Phaseolus vulgaris), mostarda (Brassica rapa), Crotalaria juncea e C. spectabilis na adesão, por borbulhamento durante $24 \mathrm{~h}$, dos endósporos de Pasteuria penetrans em juvenis do segundo estádio (J2) de M. incognita após incubação por $12 \mathrm{~h}$ nos referidos exsudatos. Barras seguidas pela mesma letra não diferem significativamente entre si pelo teste de Tukey a $5 \%$ de probabilidade.

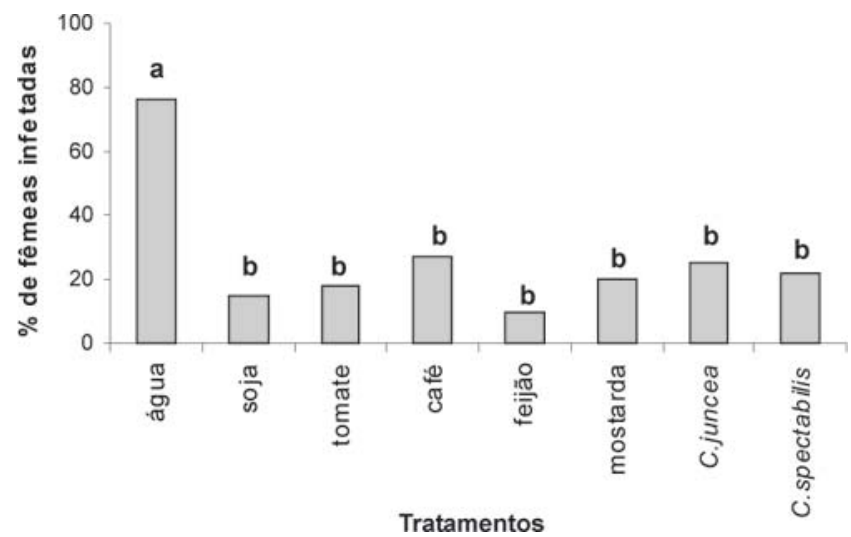

FIG. 3 - Efeito do exsudato radicular de soja (Glycine max), tomateiro (Lycopersicon esculentum), cafeeiro (Coffea arabica), feijoeiro (Phaseolus vulgaris), mostarda (Brassica rapa), Crotalaria juncea e C. spectabilis em incubação do juvenil do segundo estádio (J2) de Meloidogyne incognita por $12 \mathrm{~h}$ (ensaio 3), seguido da adesão por borbulhamento durante $24 \mathrm{~h}$ dos endósporos de Pasteuria penetrans, na infetividade da bactéria. Barras seguidas pela mesma letra não diferem significativamente entre si pelo teste de Tukey a 5\% de probabilidade.

como dito anteriormente.

A patogenicidade dos $\mathrm{J} 2$ incubados nos exsudatos e infetados por $P$. penetrans também foi diminuída quando se avaliou o número de galhas por grama de raiz de tomateiro (Figura 4).

\section{Efeito de exsudatos radiculares na adesão e infetividade de endósporos de $P$. penetrans}

Todos os exsudatos radiculares em que se incubaram os endósporos reduziram $(\mathrm{P} \leq 0,05)$ o número de endósporos por J2 de $M$. incognita comparados com os incubados em 


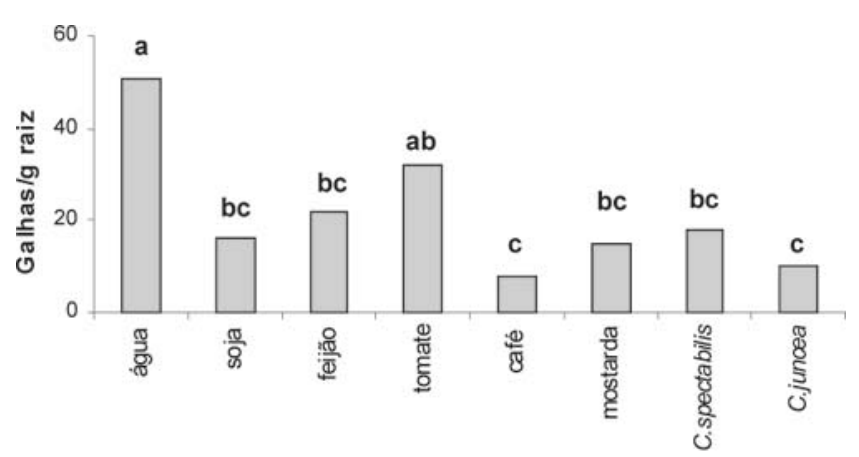

Tratamentos

FIG. 4 - Efeito de exsudato radicular de soja(Glycine max), tomateiro (Lycopersicon esculentum), cafeeiro (Coffea arabica), feijoeiro (Phaseolus vulgaris), mostarda (Brassica rapa), Crotalaria spectabilis e C. juncea, em incubação dos juvenis do segundo estádio (J2) de Meloidogyne incognita seguido da adesão de endósporos de Pasteuria penetrans, na patogenicidade dos $\mathrm{J} 2$ expressa em número de galhas/ $\mathrm{g}$ de raiz de tomateiro. Barras seguidas pela mesma letra não diferem significativamente entre si pelo teste de Tukey a $5 \%$ de probabilidade.

água (Tabela 2). A percentagem de fêmeas infetadas foi menor $(\mathrm{P} \leq 0,05)$ quando os endósporos foram tratados com exsudatos, comparados com os imersos em água (Tabela 2), cuja relação foi de 2,6 a 4,5 vezes menor. Já a relação entre o número de $\mathrm{J} 2 \mathrm{com}$ endósporos tratados com exsudato e o número de fêmeas infetadas, a partir desses J2, foi de 4,1 a 2,7.

A incubação dos endósporos nos diversos exsudatos testados afetou o processo de adesão nos J2 alterando, talvez, as cargas eletrostáticas. Afolabi et al. (1995) constataram a existência de maior rede de cargas negativas na superfície do endósporo em $\mathrm{pH}$ neutro e redução dessas cargas negativas em pH afastado do neutro. Maximiniano et al. (2001b) trabalhando com folhas moídas de $C$. juncea, verificaram também redução na adesão de endósporos de $P$. penetrans a J2 de $M$. javanica.

A percentagem menor de fêmeas infetadas em relação a $\mathrm{J} 2$ infetados com $P$. penetrans indica que muitos $\mathrm{J} 2$ na movimentação pelo solo e no processo de penetração libertaram-se dos endósporos devido à fraca adesão ocorrida quando esses endósporos foram tratados com exsudatos. Ratnasoma et al. (1991) testaram o efeito da pectinase no desprendimento de endósporos aderidos em juvenis de $M$. javanica e verificaram que cerca de $20 \%$ dos endósporos se desprenderam da cutícula dos $\mathrm{J} 2$ tratados nessa enzima. A incubação de endósporos de $P$. penetrans em enzimas como muramidase, cujo substrato é o ácido N-acetil-murâmico, e pectinase reduziu a adesividade dos endósporos aos $\mathrm{J} 2$ de Meloidogyne spp. (Davies \& Danks, 1993; Maximiniano et al., 2001a). Além disso, apenas 20 a 30\% dos endósporos aderidos à cutícula são capazes de germinar (Sayre \& Wergin, 1977; Stirling, 1984). Nesses J2 tratados com exsudatos, o número de endósporos/J2, entre cinco e nove, é o recomendável para o sucesso do parasitismo do J2 na planta. Por outro lado, o número de endósporos/J2, quando incubados em água, foi de 14 , isto é, muito elevado, chegando a $100 \%$ de $\mathrm{J} 2$ com endósporo, o que reduziu a percentagem de fêmeas infetadas, isto é, $78 \%$, causada pela morte do J2 ou do seu impedimento de penetrar no hospedeiro (Tabela 2). Mais de 11 endósporos aderidos ao J2 diminuem a infetividade desses na planta (Souza \& Campos, 1997). Em outro estudo, Davies et al. (1988) observaram maiores reduções na penetração, chegando a $86 \%$, quando os $\mathrm{J} 2$ de $M$. incognita, contendo 15 endósporos aderidos à cutícula, foram inoculados em raízes de tomateiro.

No campo, o papel do exsudato diminuindo a infetividade do endósporo aderido ao $\mathrm{J} 2$, pode prover o equilíbrio entre parasita e hospedeiro mesmo num solo com alto nível de inoculo de $P$. penetrans, onde grande parte dos $\mathrm{J} 2$ teria endósporos aderidos. Maximiniano et al. (2001c) encontraram 65,25\% dos J2 de Meloidogyne exigua Goeldi com endósporos aderidos em cafezal naturalmente infestado, contudo, a população do nematóide nunca foi exterminada.

$\mathrm{O}$ parasitismo da população de $\mathrm{J} 2 \mathrm{com}$ endósporos aderidos em mudas de tomateiro avaliadas pelo número de galhas/g de raiz foi semelhante em todos os tratamentos, pois esse parasita obrigatório não destrói o hospedeiro (J2), precisando dele como fonte de alimento. A reprodução de $M$. incognita resultante da infecção por endósporos incubados nos exsudatos antes da adesão aos J2, foi também semelhante nos diversos tratamentos, indicando que na população infetante de J2 ocorreu produção semelhante de ovos entre J2 com alto ou baixo número de endósporos/J2.

\section{REFERÊNCIAS BIBLIOGRÁFICAS}

AFOLABI, P., DAVIES, K.G. \& O'SHEA, P.S. The eletrostatic nature of the spore of Pasteuria penetrans, the bacterial parasite of rootknot nematodes. Journal of Applied Bacteriology 79:244-249. 1995.

BADRA, T., SALEH, M.A. \& OTEIFA, B.A. Nematicidal activity and composition of some organic fertilizers and amendments. Revue de Nématologie 2:29-36. 1979.

BANZATTO, D.A. \& KRONKA, S.N. Experimentação agrícola. Jaboticabal: Funep, 1995.

CAMPOS, H.D., CAMPOS, V.P., RIBEIRO, L.O. \& CAMPOS, J.R. Efeito de exsudato radicular de Brachiaria decumbens sobre a eclosão e mobilidade de juvenis do segundo estádio de Meloidogyne javanica. Fitopatologia Brasileira 27:185-186. 2002. (Resumo).

COSTA, M.J.N., CAMPOS, V.P., PFENNING, L.H. \& OLIVEIRA, D.F. Patogenicidade e reprodução de Meloidogyne incognita em tomateiros (Lycopersicum esculentum) com aplicação de filtrados fúngicos ou extratos de plantas e de estercos animais. Nematologia Brasileira 24:219-226. 2000.

DAVIES, K.G. \& DANKS, C. Carbohydrate/protein interactions between the cuticle of infective juveniles of Meloidogyne incognita and spores of the obligate hyperparasite Pasteuria penetrans. Nematologica 39:53-64. 1993.

DAVIES,K.G., KERRY, B.R. \& FLYNN, C.A. Observations on the pathogenicity of Pasteuria penetrans, a parasite of root-knot nematodes. Annals of Applied Biology 112:491-501. 1988

FERRAZ, S. \& VALLE, L.A.C. Controle de fitonematóides por plantas antagônicas. Viçosa: UFV. 1997. 
FREITAS, L.G., MITCHELL, D.J., DICKSON, D.W. \& CHELLEMI, D.O. Soil solarization and organic amendment effects on Pasteuria penetrans. Nematologia Brasileira 24:133-146. 2000.

GOMMERS, F.J. Biochemical interactions between nematodes and plants and their relevance to control. Helminthological Abstracts 50: 9-21. 1981.

GUCKERT, A. Significance of roots and their exudates as sources of organic soil substances. Soil Utilization and Soil Fertility 4:97113. 1992. (Abstract).

HALE, M.G., FOY, C.L. \& SHAY, F.J. Factors affecting root exudation. Advanced Agronomy 24:89-109. 1971.

HEWLETT, T.E. \& DICKSON, D.W. A centrifugation method for attaching endospores of Pasteuria spp. to nematodes. Journal of Nematology 25:785-788. 1993.

HUSSEY, R.S. \& BARKER, K.R. A comparison of methods for collecting inocula of Meloidogyne spp including a new technique. Plant Disease Reporter 57:1025-1028. 1973.

LORDELLO, L.G.E. Nematóides das Plantas Cultivadas. $8^{a}$ ed. São Paulo: Editora Nobel. 1984.

LUC, M., SIKORA, R.A. \& BRIDGE, J. Plant parasitic nematodes in subtropical and tropical agriculture. Wallingford. C.A.B. International. 1990.

MAXIMINIANO, C., CAMPOS, V.P. \& SOUZA, R.M. de. Efeito de enzimas na adesão de endósporos e de raças de Meloidogyne incognita na infectividade de Pasteuria penetrans. Nematologia Brasileira 25:27-34. 2001a.

MAXIMINIANO, C., CAMPOS, V.P. \& SOUZA, R.M. de. Efeito de solo argiloso e substratos orgânico e mineral na adesão de endósporos de Pasteuria penetrans Nematologia Brasileira 25:1520. 2001b.

MAXIMINIANO, C., CAMPOS, V.P., SOUZA, R.M. de. \& ALMEIDA, A.R. de. Flutuação populacional de Meloidogyne exigua em cafezal naturalmente infestado por Pasteuria penetrans. Nematologia Brasileira 25:63-69. 2001c.

MAXIMINIANO, C., CAMPOS, V.P., SOUZA, R.M. de. \& ALMEIDA, A.R. de. Efeito do pH e filtrados bacterianos na adesão de endósporos de Pasteuria penetrans. Nematologia Brasileira 25:21-26. 2001d.

NOGUEIRA, M.A., OLIVEIRA, J.S., FERRAZ, S. \& PETERNELLI, L.A. Avaliação da atividade in vitro de extratos obtidos da parte aérea de Mucuna aterrima em relação a Meloidogyne incognita raça 3. Revista Ceres 41:506-510. 1994.

RATNASOMA, H.A., GOWEN, S.R. \& HAGUE, N. G.M. Observations on the detachment of spores of Pasteuria penetrans from pre-parasitic second-stage juveniles of Meloidogyne spp. Nematologia Mediterranea 19:225-227. 1991.

ROCHA, F.S. \& CAMPOS, V.P. Efeito de filtrados fúngicos na adesão de endósporos de Pasteuria penetrans e na infectividade e parasitismo de juvenis de segundo estádio de Meloidogyne incognita. Nematologia Brasileira 24:239-244. 2000.

ROVIRA, A.D. Plant root excretions in relation to the rhizosphere effect. IV. Influence of plant species, age of plant, light, temperature, and calcium nutrition on exudation. Plant and Soil 11:53-64.1959. ROVIRA, A.D. Plant root exudates. The Botanical Review 35:3557. 1969.

SANTIAGO, D.C., HOMECHIN, M., KRZYZANOWSKI, A.A. \& CARVALHO, S. de. Efeito antagônico de Arachis pintoi sobre Meloidogyne incognita raça 2 em solo de mata e solo esterilizado. Nematologia Brasileira 25:45-51. 2001.

SAYRE, R. M. \& WERGIN, W.P. Bacterial parasitic of plant nematodes: morphology and ultrastructure. Journal of Bacteriology 129:1091-1101. 1977.

SIQUEIRA, J. O. Biologia do solo. Lavras: MG. UFLA/ FAEPE. Editora UFLA, 1997.

SOUZA, J.T. de. \& CAMPOS, V.P. Efeito do isolado P1-UFLA de Pasteuria penetrans sobre a primeira geração de Meloidogyne javanica (Treub) Chitwood. Nematologia Brasileira 21:93-102. 1997.

SPIEGEL, Y., MOR, M. \& SHARON, E. Attachment of Pasteuria penetrans endospores to the surface of Meloidogyne javanica secondstage juveniles. Journal of Nematology 28:328-334. 1996.

STIRLING, G.R. Biological control of Meloidogyne javanica with Bacillus penetrans. Phytopathology 74:55-60. 1984.

STIRLING, G.R., BIRD, A.F. \& CAKURS, A.B. Attachment of Pasteuria penetrans spores to the cuticles of root-knot nematodes. Revue de Nématologie 9:251-260. 1986.

TANDA, A.S., ATWAL, A.S. \& BAJAJ, Y.P.S. In vitro inhibition of root-knot nematodes Meloidogyne incognita by sesame root exudate and its amino acids. Nematologica 35:115-124. 1989.

TARIQ, M., AHMAD, R. \& KHAN, S.M. Attachment of Pasteuria penetrans spores to the cuticle of Meloidogyne javanica as affected by leaf extracts of some plants. Pakistan Journal of Phytopathology 12:53-55. 2000. (Abstract). 